\title{
ANTESEDEN DARI MINAT PEMBELIAN PRODUK SHAMPO NATURAL DAN ORGANIK
}

\author{
Andrian Haro \\ Fakultas Ekonomi Universitas Negeri Jakarta \\ e-mail: andrianharo@feunj.ac.id
}

\begin{abstract}
The objective of this research is to examine the consumer purchase intention of natural and organic shampoo products based on the Theory of Planned Behavior (TPB). Specifically, this research considers that consumer values as antecedents of consumers' attitude toward buying natural and organic shampoo products. A survey was conducted with many respondents from graduate students of Magister Management, Trisakti University, Jakarta, and structural equation modeling techniques was used to test the relationships among the variables. The results show that environmental consciousness and appearance consciousness have a positive effect on attitude. Meanwhile, health consciousness has no significant effect on consumers' attitude. Moreover, the results showed that TPB predictors which consist of attitude and perceived behavioral control are significantly correlated with purchase intention for natural and organic shampoo products, but not with subjective norm. This research provides valuable insight into consumer purchase intention behavior regarding natural and organic shampoo products by examining the factors that influence consumers' attitude toward buying natural and organic shampoo products and consumers' purchase intentions for the products.
\end{abstract}

Keywords: Consumer Behaviour, Theory of Planned Behavior, Attitude, Purchase Intention, Personal Care 


\section{PENDAHULUAN}

\section{Latar Belakang Masalah}

Sejak pembahasan issue lingkungan mulai dikembangkan, masyarakat menjadi lebih sadar tentang pemeliharaan lingkungan, sehingga terciptalah sebuah perilaku konsumsi produk ramah lingkungan (eco-friendly) yang disebut "green consumerism" (Moisander, 2007). Saat ini, produk natural dan organik menjadi trend di berbagai negara di dunia. Hal tersebut dapat dilihat dengan perilaku konsumen di Amerika Serikat yang mengalami peningkatan kebutuhan atas keragaman produk hijau (green products) selain makanan organik, sebagai contoh deterjen (laundry), produk perawatan pribadi (personal care), dan produk elektronik yang hemat energi (Kim dan Chung, 2011).

Menurut Longsworth (2010), semakin berkembangnya kesadaran konsumen terhadap lingkungan di seluruh dunia telah menciptakan implikasi besar bagi industri kecantikan. Secara garis besar, pembagian kategori dari sektor ini meliputi produk perawatan kulit (skin care), perawatan rambut (hair care), makeup, fragrances, dan personal hygiene (Kumar, 2005). Dari ke lima kategori tersebut yang memiliki share terbesar dari total pengeluaran konsumen adalah produk perawatan rambut (22\%) dan perawatan kulit (16\%) (Zbib et al., 2010). Hal serupa juga terjadi di Indonesia, berdasarkan hasil riset The Nielsen Company (2011) menunjukkan sektor produk perawatan pribadi mengalami pertumbuhan cepat di pasar Indonesia sebesar 12,5\% dan menduduki peringkat ke-2 setelah sektor pangan dengan share sebesar 20,5\% dari total Indonesia grocery. Melalui riset itu pula, diperoleh data pertumbuhan tiap kategori produk perawatan pribadi yang menunjukkan pertumbuhan paling besar yaitu hair conditioner, shampo, dan perawatan kulit (skin care) berupa pembersih (cleanser), hand \& body lotion, dan pelembab (moisturizer).

Untuk produk perawatan pribadi natural dan organik telah mengalami perkembangan pesat di pasar internasional. Negara di wilayah Asia yang mengalami pertumbuhan signifikan di sektor tersebut adalah Jepang, Korea, Malaysia, Hongkong, Singapura, Taiwan, dan Thailand (Canavari et al., 2011). Di Indonesia, perkembangan pasar produk perawatan pribadi natural dan organik 
masih terbilang rendah. Akan tetapi, segmen pasar tersebut memiliki potensi yang besar di masa mendatang. Di Indonesia, produk perawatan pribadi yang bersertifikat natural dan organik berasal dari produk-produk impor yang sudah beredar di pasaran yaitu The Body Shop (Inggris) dan The Face Shop (Korea). Sedangkan untuk produk lokal lainnya belum ada yang menerapkan konsep natural dan organik. Namun, perlu diketahui bahwa terdapat produk lokal Indonesia yaitu Sariayu (Martha Tilaar) dan Mustika Ratu yang telah dikenal luas sebagai natural personal care, dimana kandungan isi produknya menggunakan bahan alami pilihan yang telah teruji secara klinis (Kline \& Company, 2011).

Menurut Kim dan Chung (2011), langkah tepat yang harus ditempuh produsen supaya bisa unggul ditengah maraknya pertumbuhan pasar produk perawatan pribadi alami dan organik adalah pemahaman yang baik atas perilaku konsumen itu sendiri. Pentingnya memahami perilaku konsumen dapat dipelajari melalui Theory of Planned Behavior (TPB) yang dirancang oleh Ajzen (1985). Banyak penelitian terdahulu yang menggunakan TPB untuk memahami perilaku konsumen terhadap produk hijau. Sebagian besar objek penelitiannya lebih menekankan kepada makanan organik dan penelitian tersebut sudah diteliti di berbagai negara di dunia (Aertsens et al., 2011; Rezai et al., 2011). Akan tetapi, masih sedikit penelitian yang menggunakan produk personal care sebagai objek penelitian. Maka dari itu, tujuan utama penelitian ini dibuat adalah untuk menguji dan memahami perilaku pembelian konsumen, khususnya dikalangan mahasiswa S2 MM Universitas Trisakti, Jakarta, terkait dengan niat untuk membeli produk shampo natural dan organik yang didasarkan pada Theory of Planned Behavior (TPB) dan consumer values sebagai anteseden dari attitude konsumen.

\section{Rumusan Masalah}

1. Apakah terdapat pengaruh health consciousness terhadap attitude?

2. Apakah terdapat pengaruh environmental consciousness terhadap attitude?

3. Apakah terdapat pengaruh appearance consciousness terhadap attitude?

4. Apakah terdapat pengaruh attitude terhadap purchase intention?

5. Apakah terdapat pengaruh subjective norm terhadap purchase intention? 
6. Apakah terdapat pengaruh perceived behavioral control terhadap purchase intention?

\section{Tujuan Penelitian}

1. Untuk menganalisis pengaruh health consciousness terhadap attitude.

2. Untuk menganalisis pengaruh environmental consciousness terhadap attitude.

3. Untuk menganalisis pengaruh appearance consciousness terhadap attitude.

4. Untuk menganalisis pengaruh attitude terhadap purchase intention.

5. Untuk menganalisis pengaruh subjective norm terhadap purchase intention.

6. Untuk menganalisis pengaruh perceived behavioral control terhadap purchase intention.

\section{KAJIAN TEORI}

\section{Theory of Planned Behavior (TPB)}

Theory of Planned Behavior merupakan sebuah model yang digunakan untuk memprediksi perilaku konsumen, dimana sebagai prediktor terbaik dari perilaku tersebut adalah niat (intention) konsumen (Lodorfos dan Dennis, 2008). Faktor-faktor yang mempengaruhi niat (intention) dalam perilaku konsumen adalah attitude, subjective norm, dan perceived behavioral control (Ajzen, 1991). Theory of Planned Behaviour telah banyak digunakan oleh peneliti untuk menjelaskan niat pembelian konsumen terhadap produk organik (Chen, 2007; Tarkiainen dan Sundqvist, 2005).

\section{Consumer Values}

Nilai (values) memberikan dasar untuk pengembangan sikap (attitude) seseorang yang menggambarkan secara jelas tentang perilaku pengambilan keputusan (Mei, 2011). Kemampuan nilai (values) untuk mempengaruhi penilaian dan pilihan seseorang yang menunjukkan bahwa adanya hubungan kuat antara values, attitude, dan behavior.

Menurut penelitian terdahulu yang meneliti tentang perilaku konsumsi makanan organik, terlihat jelas bahwa nilai-nilai (values) konsumen yang berhubungan dengan kesehatan (health) dan lingkungan (environmental) 
menunjukkan pengaruh yang positif terhadap attitude konsumen untuk membeli makanan organik (Chryssohoidis dan Krystallis, 2005). Berbeda halnya dengan produk perawatan pribadi seperti perawatan kulit, produk tersebut dapat mempengaruhi penampilan (appearance) konsumen dan menjaga penampilannya supaya tetap menarik bila menggunakannya secara teratur (Marcoux, 2000). Oleh karena itu, Kim dan Chung (2011) mengusulkan bahwa tiga consumer values yang dapat mempengaruhi attitude konsumen terhadap niat untuk membeli produk shampo natural dan organik adalah health consciousness, environmental consciousness, dan appearance consciousness.

\section{Health Consciousness}

Kesadaran akan kesehatan (health consciousness) mencerminkan kesiapan seseorang untuk melakukan sesuatu untuk kesehatannya sendiri (Chen, 2009). Kesadaran akan kesehatan merupakan orientasi mental individu yang komprehensif terhadap kesehatan. Orientasi tersebut terdiri dari sikap peduli terhadap kesehatan, bertanggung jawab terhadap kesehatan diri sendiri, dan memiliki motivasi kesehatan (Michaelidou dan Hassan, 2008).

\section{Environmental Consciousness}

Kesadaran akan lingkungan (environmental consciousness) mencerminkan niat perilaku seseorang terhadap lingkungan (Smith dan Paladino, 2010). Kesadaran akan lingkungan merupakan jenis perilaku mental yang mencerminkan pengakuan individu, pertimbangan nilai dan niat perilaku terhadap issue lingkungan (Kim, 2011). Sikap pro terhadap lingkungan ditunjukkan dengan cara yang berbeda-beda, namun pada umumnya mereka akan menunjukkan sikap peduli terhadap lingkungan hidup dan menentang issue lingkungan yang ada.

\section{Appearance Consciousness}

Kesadaran akan penampilan (appearance consciousness) merupakan bagian dari kesadaran diri dari sudut publik (public self-consciousness). Seseorang dengan kesadaran akan penampilan yang tinggi cenderung selalu memperhatikan 
penampilan dirinya dan mempertimbangkan bagaimana orang lain berpikir tentang dirinya (Fuentes, 2010). Seseorang yang sadar akan penampilan memiliki ketertarikan yang kuat terhadap suatu produk. Ketertarikan tersebut terjadi apabila produk tersebut dapat mengekspresikan dan meningkatkan citra dirinya (Sukato dan Elsey, 2009).

\section{Attitude}

Attitude adalah ungkapan perasaan seseorang manakala mereka merasa suka atau tidak suka terhadap objek tertentu seperti merek produk, pelayanan atau sebuah ide (Gracia dan De Magistris, 2007). Sedangkan sikap (attitude) terhadap produk berarti arahan atau fokus yang dilakukan konsumen terhadap produk tersebut yang didasarkan atas ketertarikan dan kesukaan (Nguyen, 2010). Dengan demikian, bila perusahaan ingin mencapai sebuah hasil yang optimal adalah sangat penting untuk memahami apa yang konsumen suka dan tidak suka atau tahu dan tidak tahu tentang produk yang ditawarkan.

\section{Subjective Norm}

Subjective norm mengacu kepada keputusan yang akan diambil oleh seseorang dilakukan dengan pertimbangan sendiri maupun atas dasar pertimbangan orang lain yang dianggap penting (Qader dan Zainuddin, 2011). Subjective norm dipahami sebagai efek dari faktor eksternal terhadap niat (intention) konsumen. Hasil penelitian yang menggunakan attribut subjective norm menunjukkan sebagai alat ukur atau prediksi yang baik dari sebuah perilaku, ketika kesejahteraan orang lain dipengaruhi oleh tindakan individu lainnya (Shah Alam dan Sayuti, 2011). Coleman et al. (2011) telah menetapkan subjective norm sebagai fungsi dari keyakinan individu yang merujuk kepada orang lain (individu atau kelompok yang berpengaruh) dimana mengharuskan mereka untuk ikut terlibat atau tidak dalam perilaku tertentu serta bersedia untuk menuruti atau tidak ajakan dari orang terdekat mereka. 


\section{Perceived Behavioral Control}

Menurut Shah Alam dan Sayuti (2011), perceived behavioral control merupakan komponen penting dalam memprediksi perilaku seseorang yang menunjukkan keyakinan tentang ada atau tidaknya faktor-faktor yang mempermudah atau menghambat dalam menampilkan tingkah laku tersebut. Faktor-faktor tersebut meliputi tersedianya atau tidak informasi, kemampuan, kesempatan dan sumber daya yang dibutuhkan untuk melakukan suatu perilaku (Ajzen dan Fishbein, 2010). Hal ini ditentukan oleh keyakinan individu tentang kekuatan dari ke dua faktor baik internal maupun eksternal untuk membantu melakukan perilaku tersebut.

\section{Purchase Intention}

Menurut Nguyen (2010), purchase intention dapat dianggap sebagai prediktor keputusan pembelian di masa depan. Sedangkan Coleman et al. (2011) berpendapat bahwa niat (intention) adalah kemungkinan bahwa seseorang akan terlibat dalam perilaku tertentu. Intention adalah penentu terbaik sebuah perilaku. Oleh karena itu, untuk mengubah perilaku seseorang, maka terlebih dahulu harus mengubah niat untuk melakukan perilaku tersebut. Namun, teori ini telah gagal untuk menjelaskan perilaku yang irrational atau impulsive. Beberapa temuan studi terdahulu menunjukkan bahwa niat perilaku seseorang tidak selalu mengarah pada perilaku yang sebenarnya. Hal ini dikarenakan kontrol individu atas perilaku tidak dijalankan seutuhnya.

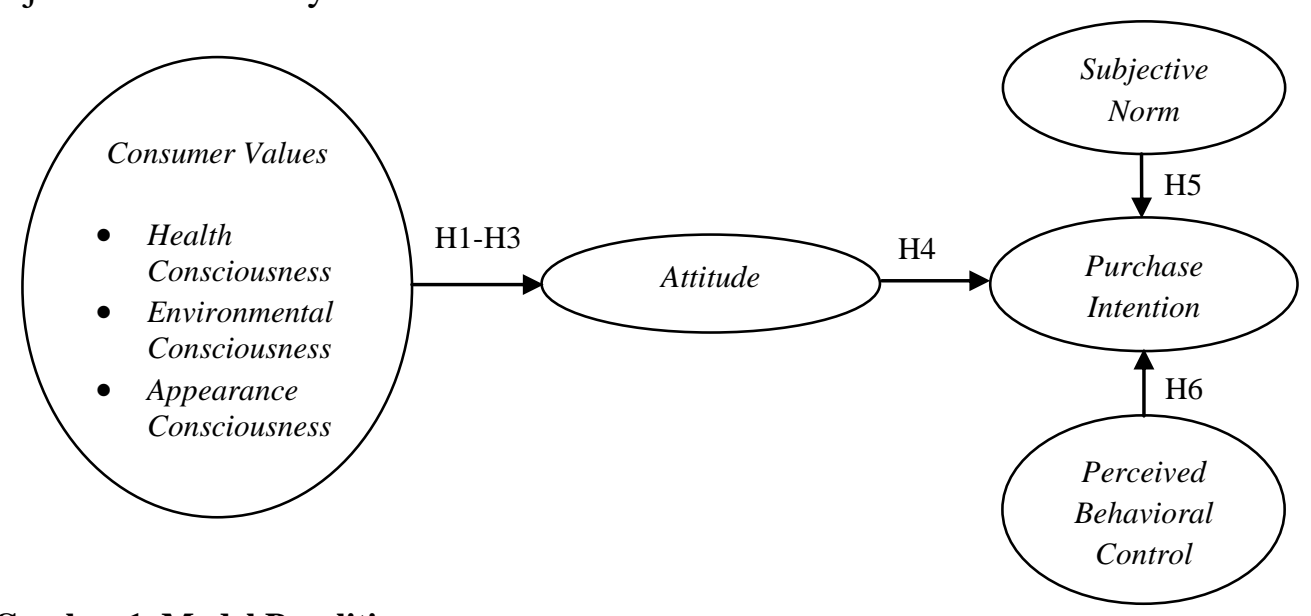

Gambar 1. Model Penelitian

Sumber: Data diolah peneliti 
Berdasarkan Gambar 1, yang menjadi hipotesis dalam penelitian ini sebagai berikut:

Hipotesis 1: Terdapat pengaruh antara health consciousness terhadap attitude.

Hipotesis 2: Terdapat pengaruh antara environmental consciousness terhadap attitude.

Hipotesis 3: Terdapat pengaruh antara appearance consciousness terhadap attitude.

Hipotesis 4: Terdapat pengaruh antara attitude terhadap purchase intention.

Hipotesis 5: Terdapat pengaruh antara subjective norm terhadap purchase intention.

Hipotesis 6: Terdapat pengaruh antara perceived behavioral control terhadap purchase intention.

\section{METODE PENELITIAN}

\section{Metode Penentuan Populasi dan Sampel}

Survei yang dilakukan dalam penelitian ini menggunakan bantuan kuesioner yang diberikan secara pribadi kepada sejumlah responden dimana hasil akhir kuesioner tersebut dapat dijadikan sumber data primer bagi peneliti (Sekaran, 2003). Oleh karena keterbatasan waktu, tempat, dan akses untuk memperoleh data dari target sampel yang diharapkan, maka dipilihlah nonprobability sampling yaitu jenis pengambilan sampel yang dipilih secara tidak acak, sehingga tidak semua unsur atau elemen populasi mempunyai kesempatan sama untuk bisa dipilih menjadi sampel (Bryman dan Bell, 2007). Teknik sampling yang digunakan berupa convenience sampling dimana penarikan sampel yang sesuai dengan ketentuan atau persyaratan sampel dari populasi tertentu yang paling mudah dijangkau atau didapatkan oleh peneliti (Sekaran, 2003). Responden dari penelitian ini yang sekaligus menjadi populasi dari sampel penelitian adalah mahasiswa S2 MM Universitas Trisakti, Jakarta, yang sudah pernah membeli dan menggunakan produk perawatan rambut yaitu shampo dalam aktivitas sehariharinya. Pemilihan sampel tersebut diharapkan bahwa para mahasiswa telah 
memiliki pengalaman dan pengetahuan yang baik dengan produk shampo yang terbuat dari bahan-bahan natural dan organik.

Ukuran sampel yang digunakan dalam penelitian ini adalah berdasarkan kriteria yang disampaikan oleh Malhotra (2004), yaitu banyaknya sampel paling sedikit 4 atau 5 kali jumlah variabel bebas yang digunakan dalam penelitian. Sampel penelitian yang telah terkumpul selama periode pengumpulan data sebanyak 204 responden, namun hanya 181 responden saja yang bisa digunakan untuk dianalisis.

\section{Metode Analisis}

Metode analisis pengolahan data yang digunakan dalam penelitian ini adalah metode SEM. Bila dalam penelitian akan melakukan analisis dengan metode Structural Equation Model (SEM), maka jumlah sampel yang ideal dan representatif yang terkumpul adalah antara 100-200 responden (Hair et al., 2006). Oleh karena itu, jumlah sampel yang terkumpul sudah memenuhi kriteria yang diinginkan dan dapat dilakukan pengujian instrumen penelitian.

\section{HASIL DAN PEMBAHASAN}

\section{Hasil Uji Instrumen}

\section{Uji Validitas}

Metode pengujian validitas menggunakan Factor Analysis yang diolah dengan software SPSS versi 11.5. Kriteria pengambilan keputusan uji validitas dengan mengamati nilai factor loadings. Secara umum jika nilai factor loadings lebih besar dari 0,50 maka item pernyataan dinyatakan valid. Hasil pengujian validitas ditampilkan pada Tabel 1 berikut ini: 
Tabel 1. Hasil Pengujian Validitas

\begin{tabular}{|c|c|c|}
\hline Konstruk / Items & $\begin{array}{c}\text { Factor } \\
\text { Loadings }\end{array}$ & Kesimpulan \\
\hline \multicolumn{3}{|l|}{ Health Consciousness } \\
\hline $\mathrm{HC} 1$ & 0,784 & Valid \\
\hline $\mathrm{HC} 2$ & 0,839 & Valid \\
\hline $\mathrm{HC} 3$ & 0,774 & Valid \\
\hline $\mathrm{HC} 4$ & 0,814 & Valid \\
\hline \multicolumn{3}{|c|}{ Environmental Consciousness } \\
\hline $\mathrm{EC} 1$ & 0,844 & Valid \\
\hline $\mathrm{EC} 2$ & 0,888 & Valid \\
\hline EC3 & 0,773 & Valid \\
\hline \multicolumn{3}{|l|}{ Appearance Consciousness } \\
\hline $\mathrm{AC} 1$ & 0,867 & Valid \\
\hline $\mathrm{AC} 2$ & 0,839 & Valid \\
\hline AC3 & 0,778 & Valid \\
\hline $\mathrm{AC} 4$ & 0,832 & Valid \\
\hline \multicolumn{3}{|l|}{ Attitude } \\
\hline ATT1 & 0,882 & Valid \\
\hline ATT2 & 0,923 & Valid \\
\hline ATT3 & 0,891 & Valid \\
\hline ATT4 & 0,895 & Valid \\
\hline \multicolumn{3}{|l|}{ Subjective Norm } \\
\hline SN1 & 0,869 & Valid \\
\hline SN2 & 0,933 & Valid \\
\hline SN3 & 0,890 & Valid \\
\hline \multicolumn{3}{|c|}{ Perceived Behavioral Control } \\
\hline PBC1 & 0,898 & Valid \\
\hline $\mathrm{PBC} 2$ & 0,888 & Valid \\
\hline $\mathrm{PBC} 3$ & 0,483 & Tidak Valid \\
\hline \multicolumn{3}{|c|}{ Perceived Behavioral Control } \\
\hline PBC1 & 0,924 & Valid \\
\hline $\mathrm{PBC} 2$ & 0,924 & Valid \\
\hline \multicolumn{3}{|l|}{ Purchase Intention } \\
\hline PI1 & 0,932 & Valid \\
\hline PI2 & 0,937 & Valid \\
\hline PI3 & 0,927 & Valid \\
\hline
\end{tabular}

Sumber: Data diolah peneliti 
Berdasarkan hasil pengujian validitas menunjukkan bahwa seluruh item pernyataan dari masing-masing konstruk memiliki factor loadings lebih besar dari 0,50, kecuali pada variabel/konstruk perceived behavioral control (PBC3) yang memiliki nilai factor loadings kurang dari 0,50. Oleh karena itu, harus dilakukan pembuangan indikator (PBC3) yang tidak valid di dalam pengolahan data supaya terbentuk konsistensi internal dalam pernyataan-pernyataan yang dapat membentuk konstruk dari perceived behavioral control. Dengan demikian hasil pengujian validitas dari seluruh item pernyataan pada masing-masing konstruk dapat dinyatakan valid.

\section{Uji Reliabilitas}

Uji reliabilitas digunakan untuk menunjukkan sejauh mana hasil pengukuran relatif konsisten apabila pengukuran diulangi dua kali atau lebih. Metode pengujian reliabilitas menggunakan Cronbach's Alpha yang diolah dengan software SPSS versi 16.

Cronbach's Alpha yang cukup dapat diterima (acceptable) adalah yang bernilai minimal 0,60 (Sekaran, 2003). Jika Cronbach's Alpha $\geq 0,60$ maka construct reliable dan sebaliknya jika Cronbach's Alpha $<0,60$ maka construct unreliable. Hasil pengujian reliabilitas ditampilkan pada Tabel 2 berikut ini:

Tabel 2. Hasil Pengujian Reliabilitas

\begin{tabular}{lccc}
\hline \multicolumn{1}{c}{ Konstruk } & $\begin{array}{c}\text { Jumlah } \\
\text { Item }\end{array}$ & $\begin{array}{c}\text { Cronbach's } \\
\text { Alpha }\end{array}$ & Kesimpulan \\
\hline Perceived Organic Knowledge & 4 & 0,8229 & Reliable \\
Health Consciousness & 4 & 0,8106 & Reliable \\
Environmental Consciousness & 3 & 0,7711 & Reliable \\
Appearance Consciousness & 4 & 0,8351 & Reliable \\
Attitude & 4 & 0,9186 & Reliable \\
Subjective Norm & 3 & 0,8782 & Reliable \\
Perceived Behavioral Control & 2 & 0,8261 & Reliable \\
Purchase Intention & 3 & 0,9239 & Reliable \\
\hline
\end{tabular}

Sumber: Data diolah peneliti 


\section{Uji Goodness-of-Fit}

Hasil pengukuran tingkat kesesuaian model ditampilkan pada Tabel 3 di bawah ini:

Tabel 3. Hasil Pengujian Kesesuaian Model

\begin{tabular}{llll}
\hline $\begin{array}{l}\text { Goodness-of-fit } \\
\text { Measures }\end{array}$ & $\begin{array}{l}\text { Level of } \\
\text { Acceptable Fit }\end{array}$ & $\begin{array}{l}\text { Nilai } \\
\text { Indikator }\end{array}$ & Kesimpulan \\
\hline $\begin{array}{l}\text { Absolute fit measures } \\
\text { Chi-Square }\left(X^{2}\right)\end{array}$ & Closed to 0 & 400,201 & poor fit \\
$\mathrm{df}$ & & 96 & \\
$p$-value & $>0,05$ & 0,000 & poor fit \\
GFI & Closed to 1 & 0,809 & marginal fit \\
RMSEA & $<0,08$ & 0,133 & poor fit \\
Incremental fit measures & & & \\
TLI & $>0,90$ or closed to 1 & 0,804 & marginal fit \\
NFI & $>0,90$ or closed to 1 & 0,806 & $\begin{array}{l}\text { marginal fit } \\
\text { marginal fit }\end{array}$ \\
CFI & $>0,90$ or closed to 1 & 0,843 & poor fit \\
AGFI & $>0,90$ or closed to 1 & 0,730 & \\
Parsimonious fit measures & & & marginal fit \\
Chi-Square $\left(X^{2}\right) / \mathrm{df}$ & $(1-5)$ & 4,169 & marginal fit \\
PRATIO & Closed to 1 & 0,800 & \\
\hline
\end{tabular}

Sumber: Data diolah peneliti

Hasil uji kesesuaian model dengan melihat nilai Chi-Square $\left(X^{2}\right) 400,201$ dengan p-value 0,000 kurang dapat diterima. Maka uji kesesuaian model perlu diamati dengan melihat kriteria lainnya yaitu $\mathrm{GFI}=0,809, \mathrm{TLI}=0,804, \mathrm{NFI}=$ $0,806, \mathrm{CFI}=0,843$, dan $\mathrm{AGFI}=0,730$. Nilai-nilai tersebut masih dapat diterima walaupun dengan tingkat penerimaan marginal fit. Pada parsimonious fit measures, kriteria PRATIO menunjukkan nilai 0,800 yang mendekati 1 dan ChiSquare $\left(X^{2}\right)$ /df sebesar 4,169 dimana nilai tersebut masih dapat diterima karena tidak melebihi nilai batas interval yang disarankan oleh Arbuckle dan Wothke (2004). Berdasarkan kriteria-kriteria pengujian tersebut, maka disimpulkan bahwa model penelitian dapat memenuhi kriteria uji kesesuaian model. 


\section{Hasil Uji Hipotesis}

Pengambilan keputusan uji hipotesis membandingkan p-value dengan level of significant sebesar 5\% (alpha 0,05). Jika p-value kurang dari alpha 0,05 maka $\mathrm{H}_{0}$ ditolak, dan sebaliknya jika $p$-value lebih besar atau sama dengan alpha 0,05 maka $\mathrm{H}_{0}$ gagal ditolak. Hasil pengujian hipotesis dapat dilihat pada Tabel 4 .

Tabel 4. Hasil Pengujian Hipotesa

\begin{tabular}{|c|c|c|c|c|c|c|}
\hline \multicolumn{4}{|c|}{ Path } & \multirow{2}{*}{$\begin{array}{l}\text { Beta } \\
-0,005\end{array}$} & \multirow{2}{*}{$\begin{array}{l}p \text { - } \\
\text { value }\end{array}$} & \multirow{2}{*}{$\begin{array}{l}\text { Kesimpulan } \\
\mathrm{H}_{1} \text { tidak didukung }\end{array}$} \\
\hline $\mathrm{H}_{1}$ & $\begin{array}{l}\text { Health Consciousness } \\
\text { Environmental }\end{array}$ & $\rightarrow$ & Attitude & & & \\
\hline $\mathrm{H}_{2}$ & Consciousness & $\rightarrow$ & Attitude & 0,135 & 0,027 & $\mathrm{H}_{2}$ didukung \\
\hline $\mathrm{H}_{3}$ & Appearance Consciousness & $\rightarrow$ & $\begin{array}{l}\text { Attitude } \\
\text { Purchase }\end{array}$ & 0,117 & 0,034 & $\mathrm{H}_{3}$ didukung \\
\hline $\mathrm{H}_{4}$ & Attitude & $\rightarrow$ & $\begin{array}{l}\text { Intention } \\
\text { Purchase }\end{array}$ & 0,893 & 0,000 & $\mathrm{H}_{4}$ didukung \\
\hline $\mathrm{H}_{5}$ & $\begin{array}{l}\text { Subjective Norm } \\
\text { Perceived Behavioral }\end{array}$ & $\rightarrow$ & $\begin{array}{l}\text { Intention } \\
\text { Purchase }\end{array}$ & $-0,014$ & 0,703 & $\mathrm{H}_{5}$ tidak didukung \\
\hline $\mathrm{H}_{6}$ & Control & $\rightarrow$ & Intention & 0,154 & 0,008 & $\mathrm{H}_{6}$ didukung \\
\hline
\end{tabular}

Sumber: Data diolah peneliti

Pada pengujian hipotesis 1 diketahui p-value 0,925 > alpha 0,05. Maka $\mathrm{H}_{01}$ gagal ditolak $\left(\mathrm{H}_{\mathrm{a} 1}\right.$ tidak didukung) artinya tidak terdapat pengaruh antara health consciousness terhadap attitude. Pada pengujian hipotesis 2 diketahui $p$ value $0,027<$ alpha 0,05 . Maka $\mathrm{H}_{02}$ ditolak $\left(\mathrm{H}_{\mathrm{a} 2}\right.$ didukung) artinya terdapat pengaruh antara environmental consciousness terhadap attitude, yaitu semakin meningkatnya environmental consciousness, maka semakin meningkat pula attitude. Pada pengujian hipotesis 3 diketahui p-value 0,034 < alpha 0,05 dengan nilai beta sebesar 0,117. Maka $\mathrm{H}_{03}$ ditolak $\left(\mathrm{H}_{\mathrm{a} 3}\right.$ didukung) artinya terdapat pengaruh antara appearance consciousness terhadap attitude, yaitu semakin meningkatnya appearance consciousness, maka semakin meningkat pula attitude. Pada pengujian hipotesis 4 diketahui $p$-value $0,000<$ alpha 0,05 dengan nilai beta sebesar 0,893. Maka $\mathrm{H}_{04}$ ditolak $\left(\mathrm{H}_{\mathrm{a} 4}\right.$ didukung) artinya terdapat pengaruh antara attitude terhadap purchase intention, yaitu semakin meningkatnya attitude, maka semakin meningkat pula purchase intention. Pada pengujian hipotesis 5 diketahui p-value $0,703>$ alpha 0,05 . Maka $\mathrm{H}_{05}$ gagal ditolak $\left(\mathrm{H}_{\mathrm{a} 5}\right.$ tidak didukung) artinya tidak terdapat pengaruh antara subjective norm terhadap purchase intention. Pada 
pengujian hipotesis 6 diketahui p-value 0,008 < alpha 0,05 dengan nilai beta sebesar 0,154 . Maka $\mathrm{H}_{06}$ ditolak $\left(\mathrm{H}_{\mathrm{a} 6}\right.$ didukung) artinya terdapat pengaruh antara perceived behavioral control terhadap purchase intention. Semakin meningkat perceived behavioral control, maka semakin meningkat pula purchase intention.

\section{Pembahasan}

Hasil pengujian ini menunjukkan hasil yang sama dengan penelitian yang dilakukan oleh Kim dan Chung (2011), dimana kesadaran akan lingkungan (environmental consciousness) dan kesadaran akan penampilan (appearance consciousness) berpengaruh secara positif terhadap sikap (attitude) untuk membeli produk shampo natural dan organik dikalangan mahasiswa S2 MM Universitas Trisakti, Jakarta. Sedangkan tingkat kesadaran akan kesehatan (health consciousness) konsumen dari masing-masing penelitian menunjukkan hasil yang tidak berpengaruh terhadap sikap (attitude) untuk membeli produk shampo natural dan organik. Hal ini dikarenakan tingkat health consciousness konsumen lebih dikaitkan kepada makanan yang dikonsumsi dan kegiatan fisik yang rutin dilakukan (Bhangale, 2011).

Selanjutnya hasil pengujian ini menunjukkan hasil yang sama dengan penelitian yang dilakukan oleh Kim dan Chung (2011), dimana seseorang cenderung akan melakukan suatu perilaku, jika orang tersebut memiliki sikap positif terhadap perilaku tersebut. Hal ini dapat ditunjukkan melalui nilai indeks beta terbesar yaitu 0,893 yang berarti bahwa konsumen yang memiliki sikap yang positif untuk membeli produk shampo natural dan organik cenderung akan melakukan pembelian terhadap produk tersebut. Kemudian hasil pengujian ini menunjukkan hasil yang berbeda dengan penelitian yang dilakukan oleh Kim dan Chung (2011), dimana tidak terdapat pengaruh antara subjective norm terhadap purchase intention dengan kata lain bahwa seseorang cenderung tidak membutuhkan pendapat orang lain saat membeli produk shampo natural dan organik. Hal ini dapat dikarenakan alasan utama seseorang membeli produk shampo natural dan organik adalah karena mereka sangat peduli dengan produk perawatan yang aman dan sehat untuk rambut mereka, bukan karena tekanan atau 
opini orang lain untuk membeli produk tersebut. Selain itu, hasil pengujian ini menunjukkan hasil yang sama dengan penelitian yang dilakukan oleh Kim dan Chung (2011), dimana semakin besar kontrol yang dimiliki oleh konsumen, maka semakin tinggi niat belinya. Dalam hal ini, ketika konsumen percaya bahwa mereka memiliki sumber daya seperti waktu dan uang yang lebih, maka persepsi mereka terhadap kontrol yang dimiliki juga ikut meningkat (Rezai et al., 2011).

\section{KESIMPULAN DAN SARAN}

\section{Kesimpulan}

Penelitian ini bertujuan untuk menguji dan memahami perilaku pembelian konsumen terkait dengan minat pembelian (purchase intention) produk shampo natural dan organik yang didasarkan pada Theory of Planned Behavior (TPB) dan consumer values. Dari hasil penelitian yang telah dilakukan kepada konsumen dikalangan mahasiswa S2 MM Universitas Trisakti, Jakarta, dapat disimpulkan untuk hasil pengukuran consumer values yang terdiri dari tiga indikator menunjukkan bahwa environmental consciousness dan appearance consciousness memberikan pengaruh signifikan dan positif terhadap attitude, dengan indeks beta sebesar 0,135 dan 0,117. Sedangkan indikator lainnya berupa health consciousness tidak berpengaruh sama sekali. Selain itu, hasil penelitian menunjukkan bahwa prediktor TPB yang memberikan pengaruh signifikan dan positif terhadap purchase intention adalah attitude dan perceived behavioral control, dengan indeks beta masing-masing sebesar 0,893 dan 0,154. Sedangkan subjective norm tidak memberikan pengaruh terhadap purchase intension.

\section{Saran}

\section{Saran Secara Teori}

Penelitian lebih lanjut disarankan sebagai berikut ini: (1). Mengaplikasikan berbagai kategori produk natural dan organik personal care lainnya, sehingga hasil penelitian dapat digeneralisasi secara keseluruhan; (2). Menambahkan faktor-faktor lain yang ikut mempengaruhi attitude dan purchase intention konsumen terhadap produk natural dan organik personal care seperti 
health environment; (3). Mengubah desain sampel menjadi probability sampling dengan metode random sampling, sehingga hasil penelitian dapat digeneralisasikan; (4). Menambah jumlah responden sebagai subjek penelitian dengan mempertimbangkan profil demografi dan geografi.

\section{Saran Praktis}

Penelitian ini memberikan rekomendasi kepada pihak produsen terutama pemasar produk kosmetik dan personal care berupa pengembangan strategi pemasaran yang efektif dan efisien dengan menekankan keindahan ekologi, keamanan produk, dan harga yang terjangkau bagi konsumen. Strategi pemasaran tersebut dapat dilakukan melalui (1). Melakukan kampanye go-green dan pemasaran hijau dengan mengedepankan penggunaan bahan-bahan alami dan organik yang ramah lingkungan dan bebas bahan kimia berbahaya pada produk perawatan kulit, sehingga membuat konsumen sadar akan pentingnya menjaga kesehatan dan melestarikan lingkungan melalui pembelian produk shampo natural dan organik; (2). Menambahkan label atau logo serta informasi yang berhubungan dengan manfaat dari bahan-bahan alami dan organik pada produk perawatan rambut; (3). Memberikan diskon atau promo bagi konsumen yang membeli produk shampo natural dan organik dan sampel gratis; (4). Melakukan segmentasi pasar yang bertujuan untuk memahami kebutuhan dan keinginan konsumen di setiap daerah.

\section{DAFTAR RUJUKAN}

Aertsens, J., Mondelaers, K., Verbeke, W., Buysse, J. dan Huylenbroeck, G.V. 2011. The influence of subjective and objective knowledge on attitude, motivations and consumption of organic food. British Food Journal, Vol. 113 No. 11 pp. 1353-1378.

Ajzen, I. 1985. From Cognition to Behavior. Kuhl, J. and Beckmann, J. (Eds). New York: Springer.

Ajzen, I. 1991. The theory of planned behavior. Organization Behavior and Human Decision Processes, Vol. 50 No. 2 pp. 179-211. 
Ajzen, I. dan Fishbein, M. 2010. Predicting and changing behavior. New York: Taylor and Francis Group, LLC.

Arbuckle, J.L. dan Wothke, W. 2004. W. Amos 4.0 User's Guide. Chicago: SmallWaters Corporation.

Bhangale, S. 2011. Health consciousness among tribal and rural population. Indian Streams Research Journal, Vol. 1 No. 2 pp. 37-41.

Bryman, A. dan Bell, E. (2007), Business Research Methods, $2^{\text {nd }}$ edition, Oxford University Press Inc., New York.

Canavari, M., Wongprawmas, R., Tomasin, G., Riedel, B., Hingley, M., Galanti, G. dan Cozzo, R. 2011. The perception of European operators toward Thai natural skin care products. The European Union's TEC II programme for Thailand, SCRIPT Project.

Chen, M.F. 2007. Consumer attitudes and purchase intentions in relation to organic foods in Taiwan: moderating effects of food-related personality traits. Food Quality and Preference, Vol. 18 No. 7 pp. 1008-21.

Chen, M.F. 2009. Attitude toward organic foods among Taiwanese as related to health consciousness, environmental attitudes, and the mediating effects of a healthy lifestyle. Journal of British food, Vol. 111 No. 2 pp. 165-178.

Coleman, L.J., Bahnan, N., Kelkar, M., dan Curry, N. 2011. Walking the walk: How the theory of reasoned action explains adult and student intentions to go green. Journal of Applied Business Research, Vol. 27 No. 3 pp. 107-116.

Fuentes, A.J. 2010. A study on attachment, emotional intelligence, and body image. Thesis, California State University, Sacramento.

Gracia, A. dan De Magistris, T. 2007. Organic food product purchase behaviour: a pilot study for urban consumers in the south of Italy. Spanish Journal of Agricultural Research, Vol. 5 pp. 439-51.

Hair, J.F., Black, W.C., Babin, B., Anderson, R.E., dan Tatham, R.L. 2006. Multivariate Data Analysis, $6^{\text {th }}$ edition. NJ: Prentice Hall International, Inc..

Kim, Y. 2011. Understanding green purchase: The influence of collectivism, personal values and environmental attitudes, and the moderating effect of 
perceived consumer effectiveness. Seoul Journal of Business, Vol. 17 No. 1 pp. 65-93.

Kim, H.Y. dan Chung, J.E. 2011. Consumer purchase intention for organic personal care products. Journal of Consumer Marketing, Vol. 28 No.1 pp. $40-47$.

Kline \& Company, Inc. 2011. Natural personal care 2010: Global market analysis and competitive brand assessment, $4^{\text {th }}$ edition, www.KlineGroup.com

Kumar, S. 2005. Exploratory analysis of global cosmetic industry: major players, technology and market trends. Technovation, Vol. 25 No. 11 pp. 1263-1272.

Lodorfos, G.N. dan Dennis, J. 2008. Consumers' intent: in the organic food market. Journal of Food Products Marketing, Vol. 14 No. 2 pp. 17-38.

Longsworth, A.P. 2010. The case for sustainability in beauty: Growing ecoawareness has big implications for the beauty industry. GCI Magazine, pp. $38-40$.

Malhotra, N.K. 2004. Marketing Research: An Applied Orientation, $4^{\text {th }}$ edition. NJ: Pearson Education, Inc.

Marcoux, D. 2000. Appearance, cosmetics, and body art in adolescents. Dermatologic Clinics, Vol. 18 No. 4 pp. 667-73.

Mei, Y.S. 2011. A study on consumer purchase intention for green personal care and cosmetic products in Malaysia. Thesis, University of Malaya, Malaysia.

Michaelidou, N. dan Hassan, L.M. 2008. The role of health consciousness, food safety concern, and ethical identity on attitudes and intentions towards organic food. International Journal of Consumer Studies, Vol. 32 No. 2 pp. 163-70.

Moisander, J. 2007. Motivational complexity of green consumerism. International Journal of Consumer Studies, Vol. 31 No. 4 pp. 404-9.

Nguyen, P.T. 2010. A Comparative Study Of The Intention To Buy Organic Food Between Consumers In Northern And Southern Vietnam. Research Paper, Assumption University, Vietnam. 
Qader, I. K. dan Zainuddin, Y. 2011. The impact of media exposure on intention to purchase green electronic products amongst lecturers. International Journal of Business and Management, Vol. 6 No. 3 pp. 240-248.

Rezai, G., Mohamed, Z., Shamsudin, M.N. dan Teng, P.K. 2011. Demographic and attitudinal variables associated with consumers' intention to purchase green produced foods in Malaysia. International Journal of Innovation Management and Technology, Vol. 2 No. 5.

Sekaran, U. 2003. Research methods for business. USA: John Wiley \& Son.

Shah Alam, S. dan Sayuti, N.M. 2011. Applying the theory of planned behavior (TPB) in halal food purchasing. International Journal of Commerce and Management, Vol. 21 No. 1 pp. 8-20.

Smith, S. dan Paladino, A. 2010. Eating clean and green? Investigating consumer motivations towards the purchase of organic food. Austrasian Marketing Journal, Vol. 18 pp. 93-104.

Sukato, N. dan Elsey, B. 2009. A model of male consumer behaviour in buying skin care products in Thailand. ABAC Journal, Vol. 29 No. 1 pp. 39-52.

Tarkiainen, A. dan Sundqvist, S. 2005. Subjective norms, attitudes and intentions of Finnish consumers in buying organic food. British Food Journal, Vol. 107 No. 11 pp. 808 - 822.

The Nielsen Company. 2011. Indonesia market outlook, the next level consumerism. The Nielsen Company, Indonesia.

Zbib, I.J., Wooldridge, B.R., Ahmed, Z.U. dan Benlian, Y. 2010. Purchase of global shampoo brands and the impact of country of origin on Lebanese consumer. Journal of Product \& Brand Management, Vol. 19 No. 4 pp. $261-275$. 